\title{
DESCRIPTION ON THE PATIENTS' CHARACTERISTICS OF ABNORMAL UTERINEBLEEDING BASED ON STRUCTURAL AND NON-STRUCTURAL ETIOLOGY
}

\author{
Silvia Maya Ananta ${ }^{1 *}$, Jimmy Yanuar Annas ${ }^{2}$, Lilik Herawati ${ }^{3}$ \\ ${ }^{1}$ Midwifery Program, Faculty of Medicine, Airlangga University, Surabaya, 60131, Indonesia \\ ${ }^{2}$ Obstetric and Gynecology Department, , Dr. Soetomo District General Hospital, Surabaya, 60285, Indonesia \\ ${ }^{3}$ Physiology Departement, Faculty of Medicine, Airlangga University, Surabaya, 60131, Indonesia
}

\section{INFORMASI ARTIKEL:}

\section{Riwayat Artikel:}

Tanggal diterima: Maret 2021

Tanggal di revisi: Maret 2021

Tanggal di Publikasi: April 2021

Key Word: Abnormal Uterine

Bleeding,Symptom, PALM, COEIN

\section{A B S T R A C T}

Abnormal uterine bleeding (AUB) is a problem frequently experienced by women in the world. AUB is not a disease but a symptom that indicates a problem in the female reproductive system or organs. The purpose of research was to determine the description of the patients' caracteristics of AUB with structural (PALM) and nonstructural (COEIN) etiologies. This analytical description study used medical record data from AUB patient in Dr. Soetomo District General Hospital Surabaya in January-December 2019. The number of samples of this study was 65 data, with 36 data for structural etiologies (PALM) and 29 data for non-structural etiologies (COEIN). Caracteristic of patient were seen from 3 categories, i.e., age, parity status, and body mass index (BMI) from 2 etiological categorie 


\section{INTRODUCTION}

The prevalence of cases of abnormal uterine bleeding (AUB) has occurred in most parts of the world. According to European epidemiological data in 2017, the prevalence of AUB ranges from 14-35\%. In addition, according to The International Federation of Gynecology and Obstetrics (FIGO) in 2018 taken from Singapore, Rome, and Vancouver, the prevalence of AUB is 3-30\% (Munro et al., 2018).

Although AUB is not a disease, it is a sign of a problem with the female system or organ, which will impact and affect the life cycle of women either physically, psychologically, or economically. Brenda F. Narice stated that AUB will generally affect around $14-25 \%$ in women of reproductive age (Narice, Delaney and Dickson, 2018).

Data from the 2014 national heavy menstrual bleeding audit by the Royal College of Obstetricians \& Gynecologists found that there were $15812 \mathrm{HMB}$ patients who came to the clinic in approximately one year, $83 \%$ of whom stated that they were uncomfortable with the situation. A study in the US states that one AUB patient can experience financial losses of $>2000$ dollars per year due to not being able to work plus ongoing household expenses (The Royal College of Obstetricians and Gynecologists, 2014; Whitaker and Critchley, 2016).

Abnormal uterine bleeding (AUB) is bleeding that is characterized by changes in the menstrual cycle, either from the interval or cycle length, as well as the duration of bleeding that is often found in women. The etiology of AUB itself is divided into two, i.e., structural and non-structural causes. Structural etiology is the cause of AUC due to anatomic abnormalities that can be evaluated or measured visually using several combinations of imaging and histopathological techniques, which are classified into structural etiology as polyps, adenomyosis, leiomyoma, malignancy

*Korespondensi: Silvia.maya.ananta-2016@fk.unair.ac.id and endometrial hyperplasia or abbreviated as PALM (Singh et al., 2013; Munro et al., 2018).

Non-structural etiology is the cause of AUB that cannot be seen or measured by imaging or histopathology. Things that are included in the non-structural etiology are coagulopathy, ovulatory dysfunction, endometrial, iatrogenic, and not otherwise classified or not classified as COEIN (Munro et al., 2018).

There are several factors that influence the risk of AUB, according to several studies and several theories; characteristics of age, pariety status, and body mass index (BMI) can affect the increase in the incidence of AUB. At certain ages, there can be an increase in the risk of getting AUC including during perimenopause and reproductive age, because at that age there can be several possibilities for AUB such as structural abnormalities or hormonal disorders that will affect the menstrual cycle (Marpaung, 2019).

Parity status in women is also one of the factors that influence the incidence of AUB. Nulliparous women will have a higher risk of AUB compared to multiparous women, because nulliparas do not experience a decrease in ovarian function so that hormone production related to endometrial growth continues to be produced and increases the risk of structural abnormalities, which will also affect bleeding patterns in these women (Marpaung, 2019).

Body mass index (BMI) in the obese category can increase the risk of AUB, because in obese women there is an increase in the aromatization mechanism of fat tissue so that estrogen production also increases which can cause excessive proliferation of the uterine wall (Hugh S. Taylor, MD.; Lubna Pal., MBBS, 2011).

Preventive action or knowing earlier the risk factors for AUB will help reduce the incidence of AUB, this will also minimize the adverse impact on AUB patients themselves, so it is important to know how the characteristics of 
AUB patients are as an illustration and educational material for the community so they can pay more attention to factors -factors that can increase the risk of AUB and can be avoided.

\section{METHOD}

This retrospective descriptive study used secondary data instruments of medical records of AUB patients at RSUD DR Soetomo Surabaya for the period January-December 2019. The variables of this study were age, pariety status, body mass index (BMI), and etiology of PUA (Structural and NonStructural). The population of this study was the patients diagnosed with abnormal uterine bleeding (AUB) at RSUD DR Soetomo Surabaya for the period January-December 2019. The sample of the study was AUB patients at the obstetrics polyclinic of RSUD Dr Soetomo Surabaya who met the inclusion criteria. The sample size obtained was 65 data. The inclusion criteria were patient medical record and the patient diagnosed with abnormal uterine bleeding (AUB) at $\mathrm{Dr}$ Soetomo Hospital Surabaya for the period January-December 2019 while the exclusion criteria were incomplete medical record, damaged medical records, and pregnant or postnatal patients.

The study instrument used was the patient's medical record. The sampling technique was done by purposive sampling, i.e., using the medical records of patients who were treated with a diagnosis of abnormal uterine bleeding at Dr. Hospital. Soetomo Surabaya for the period January-December 2019 who met the inclusion criteria. The study was conducted from September 2019 to July 2020. The analysis was carried out using Microsoft Excel 2016.

\section{RESULT AND DISCUSSION}

Table 1 Etiology of AUB

\begin{tabular}{lll}
\hline \hline \multirow{2}{*}{ Etiology of PUA } & \multicolumn{2}{l}{ Total } \\
\cline { 2 - 3 } & F & $\%$ \\
\hline \hline Struktural (PALM) & 36 & $55 \%$ \\
Non-Struktural (COEIN) & 29 & $45 \%$ \\
\hline Total & $\mathbf{6 5}$ & $\mathbf{1 0 0 \%}$
\end{tabular}

Based on Table 1 regarding the etiologic description of AUB in obstetrical polyclinic patients at RSUD Dr. Soetomo Surabaya, the largest percentage of AUB etiology was structural etiology with a percentage of $55 \%$, while non-structural etiology with $45 \%$.

The results of this study are in line with several opinions and research, such as research conducted by Kanika singh et al from 300 patients: there were 175 patients causing PALM, for the cause of COEIN there were 125 patients. In addition, research at Sumber Waras Hospital Jakarta showed that the main cause of AUB was due to structural abnormalities (Singh et al., 2013; Dewi et al., 2020).

The large percentage of structural etiology of AUB was because this study was conducted at a referral center hospital, where the referral hospital had more adequate medical personnel and equipment for diagnosing the causes of structural AUB so that more cases of anatomical and structural abnormalities were detected.

Table 2 Characteristics of AUB patients by

\begin{tabular}{lcccc}
\hline \multirow{2}{*}{ Age } & \multicolumn{3}{c}{ Total } \\
\cline { 2 - 5 } & $\begin{array}{c}\text { Structural } \\
\text { Etiology }\end{array}$ & \multicolumn{2}{c}{$\begin{array}{c}\text { Non- } \\
\text { Structural } \\
\text { Etiology }\end{array}$} \\
\cline { 2 - 5 } & $\mathrm{F}$ & $\%$ & $\mathrm{~F}$ & $\%$ \\
\hline <25 years & 5 & $14 \%$ & 13 & $45 \%$ \\
$\mathbf{2 5 - 4 0}$ years & 13 & $36 \%$ & 10 & $34 \%$ \\
$\mathbf{4 1 - 5 0}$ years & 13 & $36 \%$ & 6 & $21 \%$ \\
$\mathbf{2 5 1}$ years & 5 & $14 \%$ & 0 & $0 \%$ \\
\hline Total & 36 & $100 \%$ & 29 & $100 \%$ \\
\hline \multicolumn{3}{c}{ age }
\end{tabular}

Table 2 shows that 13 patients with structural etiology AUB were aged 25-40 years and 4150 years, while for non-structural etiology most patients aged $<25$ years were 13 patients.

The influence of age on the incidence of AUB can be associated with changes in organs in the body such as the uterus and ovaries and the HPO-Axis such as the hypothalamus and pituitary which also affect the production of 
reproductive hormones (Hugh S. Taylor, MD.; Lubna Pal, MBBS, 2011).

At the extreme ages of women, such as at the beginning and at the end of the reproductive period, it is the most common period for AUB patients. In this study, the majority of AUB structural etiology patients aged 25-40 years and 41-50 years. At the age that enters the perimenopausal phase, many changes occur and begin to experience a decline, both physically, psychologically, and hormonally related to a decrease in the number of ovarian follicles and an increase in resistance to gonadotropin stimulation, causing a decrease in estradiol levels and the endometrium is unable to maintain its normal growth. (Marpaung, 2019).

The hormone estrogen which is still secreted in the perimenopausal phase makes the endometrial wall continue to proliferate and produce excess tissue. However, it is not balanced with the secretion of the hormone progesterone so that there is nothing to maintain the endometrial wall, and in certain conditions it can increase the possibility of structural abnormalities or other conditions that cause bleeding.

The hormone estrogen which is still secreted in the perimenopausal phase makes the endometrial wall continue to proliferate and produce excess tissue. However, it is not balanced with the secretion of the hormone progesterone so that there is nothing to maintain the endometrial wall, and in certain conditions it can increase the possibility of structural abnormalities or other conditions that cause bleeding.

In other studies, it has been shown that the incidence of malignancy or structural abnormalities that cause AUB is more common in elderly women, such as Kanika sigh's study which stated that of 300 AUB patients, $56 \%$ were perimenopausal women (41-50 years) and the biggest cause is PUA-L by $30 \%$. Mary L. Marnach et al, also wrote that Adenomyosis occurs in $5-70 \%$ of women and mostly occurs in 4-5 decades of a woman's life (Khangar et al., 2018; Marnach and Laughlin-Tommaso, 2019)

AUB of non-structural etiology mostly occurs in patients aged $<25$ years. At this age, there are many possible cases that can cause AUB, such as immature HPO-Axis, PCOS, excessive strenuous exercise or inappropriate use of contraceptives.

AUB of non-structural etiology mostly occurs in patients aged $<25$ years. At this age, there are many possible cases that can cause AUB, such as immature HPO-Axis, PCOS, excessive strenuous exercise or inappropriate use of contraceptives.

A study conducted by John J.E Watania stated that $75 \%$ of early adolescents experience AUB complaints. Mary L. Marnach also revealed the etiology of PUA with characteristics of heavy and prolonged menstruation occur at the beginning of reproductive age (Marnach and Laughlin-Tommaso, 2019).

Table 4 Characteristics of AUB patients by body mass index (BMI)

\begin{tabular}{lcccc}
\hline \multirow{2}{*}{\multicolumn{1}{c}{ Age }} & \multicolumn{4}{c}{ Total } \\
\cline { 2 - 5 } & \multicolumn{2}{c}{ Structural Etiology } & $\begin{array}{c}\text { NonStructural } \\
\text { Etiology }\end{array}$ \\
\cline { 2 - 5 } & $\mathrm{F}$ & $\%$ & $\mathrm{~F}$ & $\%$ \\
\hline \hline Underweight & 3 & $8 \%$ & 5 & $17 \%$ \\
\hline Normal & 15 & $42 \%$ & 11 & $38 \%$ \\
\hline Overweight & 7 & $19 \%$ & 4 & $14 \%$ \\
\hline Obesity & 11 & $31 \%$ & 9 & $31 \%$ \\
\hline Total & 36 & $100 \%$ & 29 & $100 \%$ \\
\hline \hline
\end{tabular}

In table 4, it can be seen that from both structural and non-structural etiologies, the highest BMI category is normal and the second largest is obesity category.

According to several opinions and previous research, obesity is a factor that influences the incidence of AUB because obese patients have high levels of free fat, high levels of free fatty acids will interfere with cell performance to respond to the hormone insulin, which functions to absorb glucose from the blood 
into cells. This allows for insulin resistance in the body.

Excess insulin hormone levels will increase androgen production in the ovaries through stimulation of cytochrome $\mathrm{P} 450 \mathrm{c} 17 \alpha$ activity. If there are many androgens, the aromatization process will also increase and estrogen hormone secretion will also increase. A decrease in SHBG will also increase the Free androgen index which also increases the level of estrogen in the body (Kasim-Karakas, Cunningham and Tsodikov, 2007; Hugh S. Taylor, MD.; Lubna Pal, MBBS, 2011)

When the levels of estrogen are high without being matched by levels of progesterone, there will be excessive proliferation of the uterine wall (Endometrium) and it is fragile and easily sheds so that the possibility of the risk of malignancy in the endometrium and the prevalence of AUC increases.

The results of this study which stated that the majority of AUB patients of both structural and non-structural etiology had a normal BMI is in line with the research conducted by Rizka Aulia at the Gynecology Polyclinic of Dr Ramelan Naval Hospital of Surabaya in 2016. The majority of AUB patients had a normal BMI of 65.8\% (Rizka Aulia Wardani, 2019).

In women with normal BMI, it is possible for AUB to occur because of other factors that influence outside of the BMI itself.

\section{CONCLUSION}

In this study it can be concluded that:

1. Etiology of AUB in RSUD Dr. Soetomo Surabaya for the January-December 2019 period was mostly structural etiology (PALM).

2. The most common age of patients with structural etiology are 25-40 years and 4150 years, while the majority of nonstructural AUB patients are $<25$ years.

3. The most parity status of AUB patients of structural and non-structural etiology are nulliparous.
4. The body mass index (BMI) of AUB patients of structural and non-structural etiology are normal.

\section{REFERENCE}

Dewi, A. K. et al. (2020) 'Gambaran Klinis dan Histopatologi Kasus-kasus Perdarahan Uterus Abnormal di Rumah Sakit Sumber Waras Jakarta', Indonesian Journal of Obstetrics \& Gynecology Science, 3(1), pp. 41-47. doi: 10.24198/obgynia.v3n1.185.

Hugh S. Taylor, MD.; Lubna Pal, MBBS, M. ;Emr. S. (2011) Speroff's CLINICAL GYNECOLOGIC ENDOCRINOLOGY AND INFERTILITY. Edited by J. Larkin. Lippincott Williams \& Wilkins.

Kasim-Karakas, S. E., Cunningham, W. M. and Tsodikov, A. (2007) 'Relation of nutrients and hormones in polycystic ovary syndrome', American Journal of Clinical Nutrition, 85(3), pp. 688-694. doi: 10.1093/ajcn/85.3.688.

Khangar, B. et al. (2018) 'Assessment of symptoms and quality of life among postmenopausal women in a tertiary care hospital in Kochi, South India: A hospitalbased descriptive study', Journal of MidLife Health, 9, pp. 185-190. doi: 10.4103/jmh.JMH.

Marnach, M. L. and Laughlin-Tommaso, S. K. (2019) 'Evaluation and Management of Abnormal Uterine Bleeding', Mayo Clinic Proceedings. doi: 10.1016/j.mayocp.2018.12.012.

Marpaung, W. S. (2019) Analisis Kasus Perdarahan Uterus Abnormal ( PUA) di Rumah Sakit Umum Pusat Haji Adam Malik Medan.

Munro, M. G. et al. (2018) 'The two FIGO systems for normal and abnormal uterine bleeding symptoms and classification of causes of abnormal uterine bleeding in the reproductive years: 2018 revisions', International Journal of Gynecology and Obstetrics, 143(3), pp. 393-408. doi: 10.1002/ijgo.12666.

Narice, B. F., Delaney, B. and Dickson, J. M. (2018) 'Endometrial sampling in low-risk patients with abnormal uterine bleeding: A systematic review and meta-synthesis', BMC Family Practice. BMC Family 
Practice, 19(1), pp. 1-13. doi: 10.1186/s12875-018-0817-3.

Rizka Aulia Wardani (2019) 'Karakteristik Wanita Dengan Perdarahan Uterus Abnormal di Poli Kandungan Rumah Sakit Angkatan Laut Dr Ramelan Surabaya Tahun 2016', 17(1), pp. $35-46$.

Singh, S. et al. (2013) 'Abnormal Uterine Bleeding in Pre-Menopausal Women', Journal of Obstetrics and Gynaecology Canada. Elsevier Masson SAS, 35(5), pp. 473-475. doi: 10.1016/S1701-2163(15)30939-7.

The Royal College of Obstetricians and Gynecologists (2014) 'National heavy menstrual bleeding audit', (July), p. 47. Available at:

https://www.rcog.org.uk/globalassets/docum ents/guidelines/research-audit/national_hmb_audit_final_report_july _2014.pdf.

Whitaker, L. and Critchley, H. O. D. (2016) 'Abnormal uterine bleeding', Best Practice and Research: Clinical Obstetrics and Gynaecology. Elsevier Ltd, 34(December), pp. 54-65. doi:

10.1016/j.bpobgyn.2015.11.012. 